\title{
PETROL İÇEREN ATIK SULARIN ARITILABİLİRLİĞİ VE ARITIM SISTEMININ TASARLANMASI
}

\author{
Berrak EROL NALBUR \\ Ender KARAELLI
}

Alınma: 24.09.2018; düzeltme: 12.02.2019 ; kabul: 04.03.2019

Öz: Petrol içeren atık sular, kaynağına bağlı olarak, askıda ve çözünmüş katı madde, organik tuzlar, yağ ve gres, alifatik ve aromatik hidrokarbonlar, sülfitler ve metaller gibi oldukça karmaşık bir bileşime sahiptir. Bu içeriği nedeni ile toprak, su, hava ve insan hayatına karşı bir tehlike oluşturmaktadır. Bu nedenle, petrol atık suyu arıtımı acil çözüm gerektiren bir problem haline gelmiş olup, arıtım teknikleri konusundaki çalışmalar son zamanlarda hız kazanmıştır. Petrol içeren atık suyun arıtılması için elektrokimyasal arıtım, membran filtrasyonu, biyolojik arıtım, hibrit teknolojiler gibi pek çok yöntem uygulanmaktadır. Elektrokimyasal arıtım, membran filtrasyonu, biyolojik arıtım, hibrid teknolojiler bu yöntemlerden bazılarıdır. Bu çalışmanın amacı, bir akaryakıt depolama tesisinden kaynaklanan atık suların kimyasal arıtılabilirliğini belirleyerek, deşarj limitlerini sağlayacak bir kimyasal ve biyolojik arıtma sistemini tasarlamaktır. Araştırma sonuçlarına göre asit kraking, çözünmüş hava flotasyonu ve aktif çamur sisteminden oluşan arıtma sisteminin ardından KOİ giderim verimi \%94, askıda katı madde giderim verimi \%96 ve yağ gres giderim verimi \%98 olarak tespit edilmiştir.

Anahtar Kelimeler: Petrol atık suyu, Hidrokarbon, Atık su arıtımı

\section{Treatability of Oily Wastewater and Design of the Treatment System}

\begin{abstract}
The oily wastewater depending on the source, has a very complex composition, such as suspended and dissolved solids, organic salts, oil and grease, aliphatic and aromatic hydrocarbons, sulfides and metals. Because of this content, it poses a danger to land, water, air and human life. Therefore, oil wastewater treatment has become a problem requiring urgent solution, and studies on treatment techniques have recently gained momentum. Many methods such as electrochemical treatment, membrane filtration, biological treatment and hybrid technologies are used for the treatment of oilcontaining wastewater. Electrochemical treatment, membrane filtration, biological treatment, hybrid technologies are some of these methods. The aim of this study is to design a chemical and biological treatment system that will provide the discharge limits by determining the chemical treatability of the wastewater from a fuel storage facility. According to the results of the research, COD removal efficiency was determined as $94 \%$, suspended solids removal efficiency was $96 \%$ and oil grease removal efficiency was $98 \%$ after treatment with acid cracking, dissolved air flotation and activated sludge system.
\end{abstract}

Keywords: Oily wastewater, Hydrocarbon, Wastewater treatment

\footnotetext{
Uludağ Üniversitesi, Mühendislik Fakültesi, Çevre Mühendisliği Bölümü, 16059, Görükle, Bursa (bnalbur@uludag.edu.tr)

** Uludağ Üniversitesi, Fen Bilimleri Enstitüsü, Çevre Mühendisliği Ana Bilim Dalı, 16059, Görükle, Bursa

"Bu makale 10-12 Ekim 2017 tarihleri arasında U.Ü. Asım Kocabıyık M.Y.O. Yerleşkesi/Gemlik de düzenlenen Ulusal Çevre, Deniz ve Kıyı Kirliliği Sempozyumu'nda (UCEDKKS-2017 Bursa) sunulmuş ve yeniden değerlendirilmiştir."
} 


\section{GíRiş}

Endüstriyel gelişme ile birlikte petrol kullanımında büyük artış olmuş, fakat pek çok farklı nedenden ötürü, petrol içeren atık suyun arıtımında bazı teknik ve yönetimsel konulardan kaynaklanan eksiklikler olması nedeni ile bu tür atık sular su kaynaklarına karışarak kirliliğe yol açmışırı. Arıtılması gereken petrol atık sularının kaynakları çok geniştir. Bunların bazıları, petrol endüstrisi, petrol rafinerileri, akaryakıt depolama tesisleri, taşıma ve petrokimya endüstrileridir (Ahmed et al., 2007; Machin-Ramirez et al., 2008; Chen and He, 2003).

Petrol atık suyunun olumsuz etkilerini minimize etmek ya da gidermek için yüksek hidrokarbon, organik kirlilik ve petrol kalıntıları içeren bu atıksuya uygulanan çeşitli arıtım metotları mevcuttur. Bunlara örnek olarak elektrokimyasal arıtım, membran filtrasyonu, biyolojik arıtım, adsorpsiyon, flotasyon ve kimyasal koagülasyon, ultrason dağılımlı, nano ölçekli demir parçacıkları, titanyum dioksit ve hibrid teknolojiler sayılabilir (Jamaly ve diğ., 2015). Flotasyon ve koagülasyon, petrol atık suyunun arıtımı için uygulanan konvansiyonel metotlardan ikisidir. Flotasyon yönteminde, sudan daha az yoğun olan petrol suyun yüzeyinde yüzdürülerek giderilir. Koagülasyonda, askıda katılar, kolloidler ve petrol partikülleri destabilize edilirler, böylece bir araya gelerek daha büyük floklar oluşturabilirler. Bu büyük floklar sudan daha yoğun ve ağır hale gelir, böylece çöktürülerek bertaraf edilebilirler. Petrol atık suyunun arıtımının tek bir arıtım yöntemiyle giderilemeyecek kadar zor ve karmaşık olduğu unutulmamalıdır. Bu nedenle farklı arıtım yöntemleri bir arada kullanılarak uygun bir arıtım gerçekleştirilmesi gerekebilir.

Bu çalışmanın amacı, bir akaryakıt depolama tesisinden kaynaklanan atık suların kimyasal arıtılabilirliğini belirleyerek, deşarj limitlerini sağlayacak bir kimyasal ve biyolojik arıtma sistemini tasarlamaktır.

\section{MATERYAL VE YÖNTEM}

\subsection{Akaryakıt Depolama Tesisi Yapısı}

Akaryakıt depolama olarak nitelendirilen bir tesiste genel olarak ürün depolama ve elleçleme faaliyeti yürütülmektedir. Tesis 7 gün 24 saat faaliyet göstermektedir (Şekil 1.).

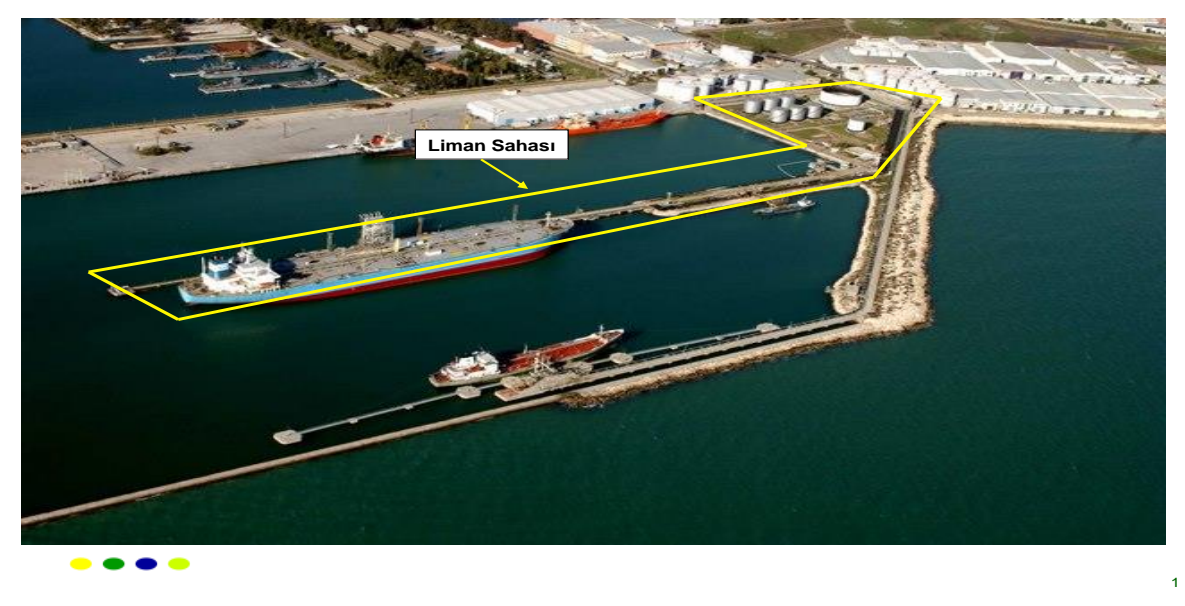

Şekil 1:

Örnek bir Akaryaklt Depolama ve Liman Sahası 
Bir depolama ve iletim tesisinde üretime bağlı herhangi bir hammadde kullanımı olmamakla birlikte akaryakıt yani motorin ve benzin işlenmiş olarak tesise gelmektedir. Çalışma yapılan tesisin akaryaktı depolama kapasitesi yaklaşık $20000 \mathrm{~m}^{3}$ olup, tesis içesinde "Gemilerden Atık Kabul Tesisi", 6 adet akaryakıt tank1 ve 2 adet Slop (atı) tank1 bulunmaktadır. Tankların kapasiteleri aşağıdaki Tablo 1. ve Tablo 2.'de verilmiştir.

Tablo 1. Akaryakıt tesisi depo hacimleri

\begin{tabular}{|c|c|c|c|c|}
\hline \multicolumn{5}{|c|}{ AKARYAKIT DEPOLAMA - LIMAN TESISI } \\
\hline & Tank No & Tank Tipi & Ürün Cinsi & $\begin{array}{c}\text { Tank Kapasitesi } \\
\left(\mathbf{m}^{3}\right)\end{array}$ \\
\hline 1. depo & TNK101 & ST37 & Benzin & 1430 \\
\hline 2. depo & TNK-102 & ST37 & Motorin & 2000 \\
\hline 3. depo & TNK-103 & ST37 & Motorin & 2000 \\
\hline 4. depo & TNK-104 & ST37 & Benzin & 2020 \\
\hline 5. depo & TNK-105 & ST37 & Benzin & 2050 \\
\hline 6. depo & TNK-106 & ST37 & Motorin & 10500 \\
\hline
\end{tabular}

Tablo 2. Tesiste bulunan diğer tanklar

\begin{tabular}{|c|c|c|c|c|}
\hline \multicolumn{5}{|c|}{ DİĞER SERVÍS TANKLARI } \\
\hline 7. depo & TNK-201 & Antrepo & Slop Tank1 & $1993\left(\mathrm{~m}^{3}\right)$ \\
\hline 8.depo & TNK-202 & Antrepo & Slop Tank1 & $1993\left(\mathrm{~m}^{3}\right)$ \\
& & & TOPLAM $\left(\mathbf{m}^{3}\right)$ & $\mathbf{3 9 8 6}$ \\
\hline
\end{tabular}

Akaryakıt ürünleri depolama tanklarının günlük durumları (seviye, sıcaklık, giriş ve çıkışlar) stok kontrol sistemine işlenmektedir.

\subsection{Atık Su Oluşumu}

Akaryakıt liman tesisinde depolama ve elleçleme faaliyetlerinden yağlı atık su çıkmaktadır. Tesis içerisinde nakiller, depolama, bakım onarım faaliyetleri sırasında oluşan yere sızma ve damlamalar sonucu yerde birikim yapan akaryakıt kalıntıları yağmurlu dönemlerde yağışla birlikte akışa geçmektedir. Bu sular denize ulaşmadan önce bir slop tankında biriktirilmektedir. Ayrıca deniz tankerleriyle gelen işlenmiş akaryakıt, depolara pompayla transferi yapıldıktan sonra borularda kalan akaryakıt suyla itilerek depolara aktarılmaktadır. Bu 
iletim aşamasında gerek akaryakıttan gelen, gerekse boru cidarlarından suya karışan akaryakıt türevi ve hidrokarbon içeriği yüksek, atık su oluşmaktadır. Bu atık sular tesiste bulunan bir slop tankında biriktirilerek dinlenmeye bırakılırlar. Bu aşamada tank içerisinde akaryakıt yoğunluk farkından dolayı tank yüzeyinde birikerek akaryakıt depolarına aktarılmakta, altta bulunan atık su bir yağ seperatöründen geçirildikten sonra arıtma tesisine gönderilmektedir.

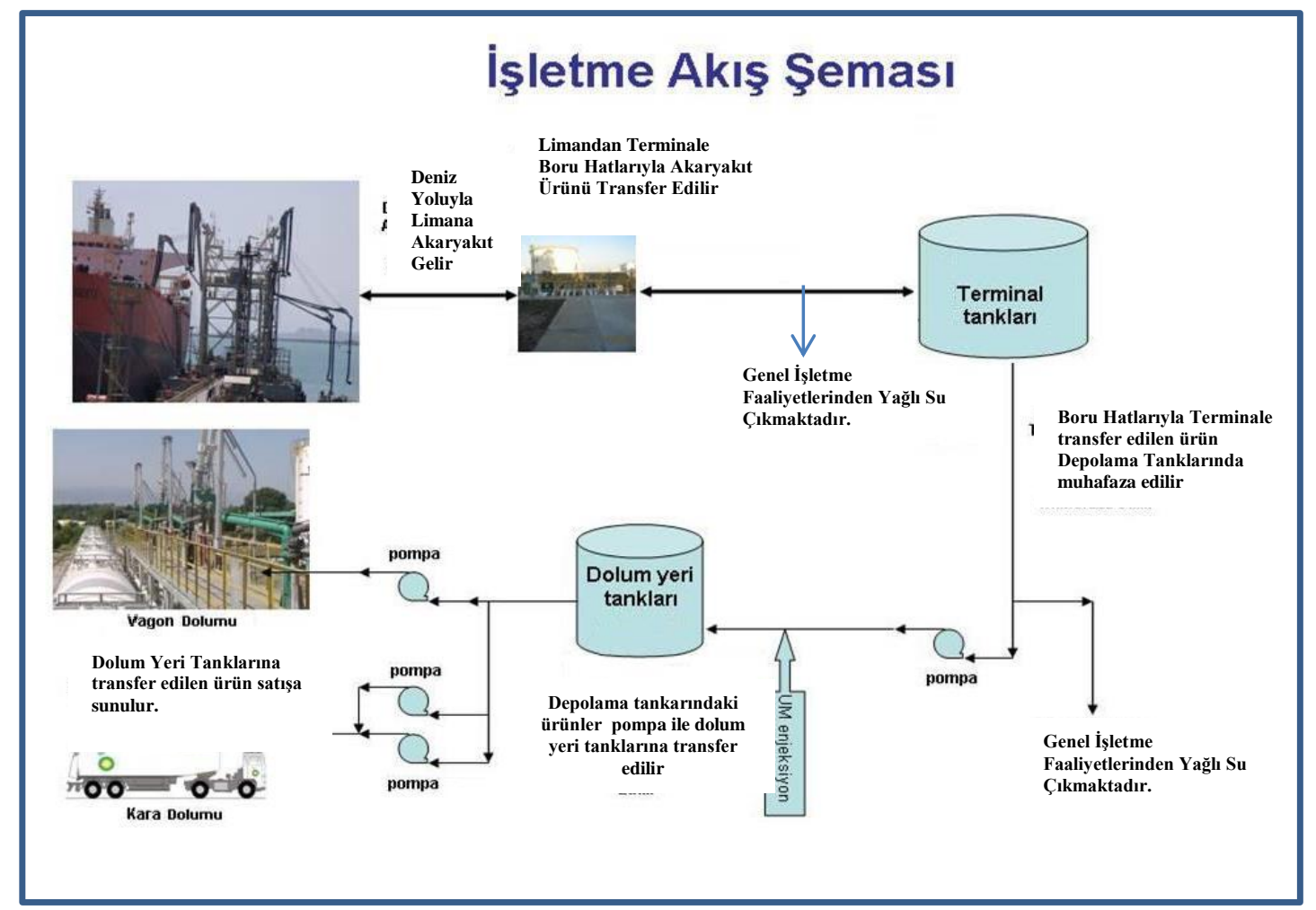

Şekil 2:

Işsletme Akım Şeması

\subsection{Atık Su Karakterizasyonu}

Akaryakıt depolama tesisinin üretim prosesi çıkışı, arıtma tesisi girişi atıksu karakterizasyonu Tablo 3'te verilmiştir.

Akaryakıt depolama tesisinin üretim prosesinde oluşan atık su karakterizasyonunu belirlenmesi için alınan kompozit numunelere ait yapılan analizler sonucu elde edilen vei projelendirmede kullanılan atıksu karakterizasyonu Tablo 3'te verilmiştir.

Tablo 3. Akaryakıt Depolama Tesisi Atık Su Karakterizasyonu

\begin{tabular}{|c|c|c|c|c|c|c|c|c|}
\hline & KOI & AKM & $\begin{array}{c}\text { YAĞ } \\
\text { GRES }\end{array}$ & $\begin{array}{c}\text { HIDRO } \\
\text { KARBONLAR }\end{array}$ & FENOL & $\begin{array}{c}\text { TOPLAM } \\
\text { SIYYANÜR }\end{array}$ & SÜLFÜR & pH \\
\hline $\begin{array}{c}\text { Atıksu } \\
\text { Arıtma Tesisi } \\
\text { projesi için } \\
\text { Atıksu } \\
\text { Karakterizas } \\
\text { yonu }\end{array}$ & 450 & 150 & 500 & 250 & 0,1 & 0,03 & 0,1 & 8 \\
\hline
\end{tabular}




\subsection{Deșarj Kriterleri}

Prosesten kaynaklanan kimyasal nitelikli atık sular için fiziko-kimyasal ve biyolojik arıtma tesisi tasarlanmıştır. Atık su arıtma tesisi, maksimum debiye ve gelebilecek pik yüklemelere bağlı olarak hesaplanıp tasarlanmıştır. Sistemde kullanılacak havuz boyutları, ekipman ve teçhizat kapasiteleri gelebilecek bu debiye göre projelendirilmiştir.

Atık sudaki kirlilik değerlerine bağlı olarak arıtılması istenilen ve Çevre ve Şehircilik Bakanlığı tarafindan 31.12.2004 tarih ve 25687 sayılı Resmi Gazete'de yayımlanarak yürürlüğe giren Su Kirliliği Kontrolü Yönetmeliği kapsamında Tablo 11.2 Sektör Petrol Sanayii (Petrol Dolum Tesisleri ve Benzerleri) deşarj standartları aşağıdaki Tablo 4.'te belirtilmiştir.

Tablo 4. SKKY Deşarj Standartları

\begin{tabular}{|l|c|c|c|c|}
\hline \multicolumn{1}{|c|}{ Parametre } & & & \multicolumn{2}{c|}{ SKKY Tablo 11.2 } \\
\cline { 3 - 5 } & Birim & Atık su & $\begin{array}{c}\text { 2 saatlik } \\
\text { komp. } \\
\text { numune }\end{array}$ & $\begin{array}{c}\text { 24 saatlik } \\
\text { komp. } \\
\text { Numune }\end{array}$ \\
\hline Kimyasal Oksijen İhtiyacı (KOİ) & & & 400 & 200 \\
\hline Askıda Katı Madde (AKM) & $\mathrm{mg} / \mathrm{L}$ & 450 & 60 & 30 \\
\hline Yağ ve Gres & $\mathrm{mg} / \mathrm{L}$ & 150 & 40 & 20 \\
\hline Hidrokarbonlar & $\mathrm{mg} / \mathrm{L}$ & 500 & 6 & 8 \\
\hline Fenol & $\mathrm{mg} / \mathrm{L}$ & 250 & 2 & 1 \\
\hline Toplam Siyanür & $\mathrm{mg} / \mathrm{L}$ & 0,1 & 0,5 & 0,2 \\
\hline Sülfür & $\mathrm{mg} / \mathrm{L}$ & 0,03 & 2 & 1 \\
\hline pH & $\mathrm{mg} / \mathrm{L}$ & 0,1 & $6-9$ & $6-9$ \\
\hline
\end{tabular}

Arıtma sistemi, ham atık su analiz sonuçları baz alınarak, Çevre ve Şehircilik Bakanlığı tarafından istenilen alıcı ortam deşarj standartlarına uygun olarak, fiziko-kimyasal ve biyolojik arıtma sistemi olarak tasarlanmıştır. Sistem tasarımında kimyasal arıtılabilirlik deneyleri jar test deneyleri ile laboratuvar ortamında gerçekleştirilmiş, bu deneyler sonucunda uygun kimyasallar ile bunların optimum dozaj miktarları belirlenmiştir.

\subsection{Deneysel Çalışma}

Atık su arıtma sistemi tasarımında kullanılmak üzere akaryakıt depolama tesisinden kaynaklanan atık suyun arıtılabilirlik çalışması için jar testi yapılmıştır. Bu test sonucuna göre arıtma tesisi tasarlanmıştır. Tesisten gelen atık sudan alınan örnek üzerinde çalışılmıştır. Çalışma öncesi atık su, hızlı karıştırma işlemi ile asit kraking işlemine tabii tutulmuştur. İşlemde atık suya \%30'luk $\mathrm{HCl}$ ilavesi yapılarak $\mathrm{pH}$ değeri 2,5'a düşürülmüştür. $20 \mathrm{dk}$. bekleme sonucu alt kısımda oluşan duru su teste tabii tutulmuştur. Reaksiyon için $\mathrm{Al}_{2}\left(\mathrm{SO}_{4}\right)_{3}$ çözeltisi kullanılmıştır. Jar testi için iki kademe uygulanmıştır. İlk kademede optimum pH değeri, ikinci kademede de optimum koagülant dozu belirlenmiştir. 


\subsubsection{Optimum pH Değerinin Belirlenmesi}

Jar testi düzeneği kullanılarak optimum pH değerinin belirlenmesi için 1000 ml'lik 2 adet reaktör kabı kullanılmıştır. Her bir reaktöre 500'er ml atık su örneği alınmıştır. Atık suyun pH değeri pH metre ile 2,5 olarak ölçülmüştür. Reaktöre alınan atık su örneklerinin asit krakingten dolayı 2,5 olan $\mathrm{pH}$ değeri \% 10'luk kireç ve \%25 lik $\mathrm{NaOH}$ ile 5,5 değerlerine ayarlanmıştır. Her bir örneğe aynı miktarda \%10'luk $\mathrm{Al}_{2}\left(\mathrm{SO}_{4}\right)_{3}$ çözeltisinden $200 \mathrm{ml}$ ilave edilmiştir. Daha sonra hızlı karıştırma işlemi yapılmış ve flok oluşumu gözlenmiştir. Ardından \% 10'luk kireç çözeltisi ve $\mathrm{NaOH}$ ilave edilerek $\mathrm{pH} 8,5$ olarak ayarlanmıştır. Flokülasyon için anyonik polielektrolit ilave edilerek karıştırma yapılmıştır. $\mathrm{pH} \mathrm{8,5'ta} \mathrm{flokların} \mathrm{yoğunluğunun} \mathrm{arttığ}$ gözlenmiştir. Karıştırma işlemi durduktan sonra örnekler 1 saat dinlendirilmeye bırakılmıştır. Dinlendirme sonucunda her bir reaktörden üstte kalan arıtılmış atık sudan örnek alınarak incelenmiştir. Deney sonunda elde edilen veriler $\mathrm{pH}$ 8,5'un optimum $\mathrm{pH}$ olduğunu göstermiştir.

Aynı işlemler $\mathrm{FeCl}_{3}$ çözeltisi için tekrarlanmıştır. İki ayrı numune kabında 500 ml'lik iki adet numune denenmiştir. pH değeri sırasıyla 3,5 ve 9'a getirilip her iki numuneye de $2 \mathrm{ml}$ $\% 30$ 'luk $\mathrm{FeCl}_{3}$ çözeltisi ilave edilmiştir. Atık su örneklerinde flok oluşumları gözlenmiş ve $\mathrm{FeCl}_{3}$ için $\mathrm{pH}$ 3,5 değerinde, $\mathrm{pH}$ 9'a göre daha iyi sonuçlar elde edilmiştir. Ancak yapılan testlerde $\mathrm{Al}_{2}\left(\mathrm{SO}_{4}\right)_{3}$ çözeltisinin $\mathrm{pH} 8,5^{\prime}$ ta en iyi sonucu verdiği gözlenmiştir.

\subsubsection{Optimum Koagülant Dozunun Belirlenmesi}

Optimum koagülant dozunun belirlenmesi için yine jar testi düzeneği kullanılmıştır. 1000 mililitrelik iki adet reaktör kabına $\mathrm{pH}$ değeri 8,5 olan 500'er mililitre atık su örneği alınmıştır. Atık su örneklerine sirasıyla \% 10'luk $\mathrm{Al}_{2}\left(\mathrm{SO}_{4}\right)_{3}$ çözeltisinden $200 \mathrm{ml}$, ve $250 \mathrm{ml}$ ilave edilerek örnekler karıştırılmıştır. Flokülasyon işlemi için \% 0.1 'lik anyonik polielektrolit çözeltisinden 2 $\mathrm{ml}$ ilave edilerek yavaş karıştırılma işlemi yapılmıştır. Karıştırma işleminden sonra 1 saat dinlendirilmeye bırakılmıştır. Dinlendirme sonucunda her bir reaktörden üstte kalan arıtılmış atık sudan örnek alınmış ve incelenmiştir. Deney sonunda \% 10'luk $\mathrm{Al}_{2}\left(\mathrm{SO}_{4}\right)_{3}$ çözeltisinden 250 $\mathrm{ml}$ dozlama yapılan numunede diğerine göre daha iyi sonuçlar elde edilmiştir.

Yapılan bu çalışmalara göre; $\mathrm{Al}_{2}\left(\mathrm{SO}_{4}\right)_{3}$ için optimum çalışma $\mathrm{pH}$ '1 8,5, kullanılan dozaj miktarı $250 \mathrm{ml}$ olarak bulunmuştur. $\mathrm{pH} \% 10$ 'luk kireç çözeltisi ve \%25'lik $\mathrm{NaOH}$ ile pH 8,5 değerine getirilmiştir. Kullanılan kireç dozajı da 4 ml'dir. Kalan bileşiklerin çöktürülmesi için kireç kullanılmıştır. Flokülasyon işlemi için \% 0,1'lik polielektrolitten $2 \mathrm{ml}$ kullanılmıştır. $\mathrm{Bu}$ dozaj miktarında çökelebilecek flokların hızının arttığı ve istenilen flokülasyon işlemi gerçekleştiği görülmüştür. 1 saatlik çökelme sonucunda dipte oluşan çamur miktarı ölçülmüş ve 500 mililitrelik örneğin 1/10'u oranında olduğu tespit edilmiştir. Çamur hesabı da bu değer göz önünde bulundurularak hesaplanmıştır.

Deneyler sonunda $\mathrm{Al}_{2}\left(\mathrm{SO}_{4}\right)_{3}{ }^{\prime}$ 'n $\mathrm{pH} 8,5$ değerinde etkin olduğu görülmüsştür. Ham atık suyun $\mathrm{pH}$ değeri 7,7 olarak ölçülmüştür. Asit kraking işleminden dolayı $\mathrm{pH}$ 2,5 düşürülmüş olduğu için \% 10'luk kireç ve \% 25'lik $\mathrm{NaOH}$, dozlanarak $\mathrm{pH} 8,5$ 'a yükseltilmiştir. $\mathrm{Al}_{2}\left(\mathrm{SO}_{4}\right)_{3}$ dozlandıktan sonra oluşan flokların daha hızlı çöktürülmesi için \% 0,1 'lik anyonik polielektrolit ilave edilmiştir. İlave edilen polielektrolit dozaj miktarı $2 \mathrm{ml}$ olarak ölçülüp optimum dozlama miktarı olarak belirlenmiştir.

\section{BULGULAR VE TARTIȘMA}

\subsection{Arıtma Tesisi Tasarımı}

Arıtma tesisi, laboratuvarda gerçekleştirilmiş olan arıtılabilirlik deneyleri doğrultusunda tasarlanmış ve arıtma tesisinin verimliliğine yönelik hesaplar elde edilen sonuçlara göre gerçekleştirilmiştir. Petrol ve hidrokarbon içeriği yüksek olan bu atık suların, basit yağ seperatöründen geçirildikten sonra suda bulunan hidorkarbon giderimine yönelik olarak bir asit kraking ünitesi tasarlanmıştır. Tasarlanan sistemde $\mathrm{pH}$ değeri 2,5'a indirilerek suda bulunan 
emülsiye yağların stabil yapısının bozulması sağlanacaktır. Yağların sudan uzaklaştırma verimliliğinin arttırılması için yağ tutucu olarak çözünmüş hava flotasyonu (DAF) sistemi uygulanacaktır. DAF sisteminde yüksek basınç ortamında sıkıştırılan hava ve su karışımı tank tabanından atmosferik koşullarda atık suya verilerek küçük hava kabarcıklarının suya difüzyonu sağlanacak, böylece atık suda bulunan yağ ve hidrokarbonların çok küçük hava kabarcıklarına tutunarak yüzeye taşınması sağlanacak ve atık sudan uzaklaştırılacaktır.

Laboratuvar ortamında gerçekleştirilen kimyasal arıtılabilirlik deneylerine göre belirlenen uygun koagülantın optimum $\mathrm{pH}$ 'ta $\left(\mathrm{Al}_{2}\left(\mathrm{SO}_{4}\right)_{3}\right.$ ve $\left.8,5 \mathrm{pH}\right)$ uygulanmas1 ile koagülasyon uygulanması düşünülmüştür. Koagülasyondan sonra atık su, flokülasyon ünitesinde \% 0,1 lik anyonik polielektrolit ile hızlı çökelebilir flokların oluşumu sağlanarak kimyasal çökeltime tabii tutulacaktır.

Tasarlanan atık su arıtma tesisinin akım şeması Şekil 3'te verilmektedir.

Tesiste endüstriyel atık suların yanı sıra personelin günlük kullanımları sonucu evsel nitelikli atık su da oluşmaktadır. 95 kişilik personelden kaynaklanan evsel nitelikli atık su miktarı günlük $10 \mathrm{~m}^{3}$ olarak belirlenmiştir. Evsel atık suların günlük debisinin çok fazla olmaması ve arıtma verimliğinin arttırılması için endüstriyel ve evsel nitelikli atık suların ortak olarak biyolojik arıtıma tabii tutulması düşünülmüştür.

Biyolojik oksidasyon için arıtma tesisi ardışık kesikli reaktör olarak tasarlanmıştır. Dengeleme havuzunda evsel ve endüstriyel nitelikli atık sular organik yük ve debi açısından dengelendikten sonra biyolojik oksidasyon için ardışı kesikli reaktöre (AKR) alınacaktır. Burada kimyasal arıtımdan gelen arıtılmış su ile evsel nitelikli atık su paçallanarak biyolojik arıtıma tabii tutulacaktır. Tesiste duş ve mutfak ünitesi bulunmadığından evsel atıksuyla gelen organik kirlilik yükü, konvansiyonel evsel atıksu karakterinden oldukça düşüktür. Bu nedenle Evsel nitelikli atıksu debisinin de çok düşük olması nedeni ile, projelendirme parametrelerine etkisi ihmal edilmiştir. AKR'de konvansiyonel karışık aktif çamur kültürünün yanı sıra yağ gideriminde etkin olan ve buna özel enzim salgılayan bakteriler kullanılarak biyolojik parçalanma verimliliği arttırılacaktır.

AKR döngü süresi 12 saat olup günde $2 \mathrm{kez}$ çalışacaktır. Havalandırma fazı 8 saat, çökeltim fazı 3 saat ve arıtılmış su tahliye fazı 1 saat olarak hesaplanmış ve havuz boyutları bu hesaplamalar üzerinden tasarlanmıştır. 


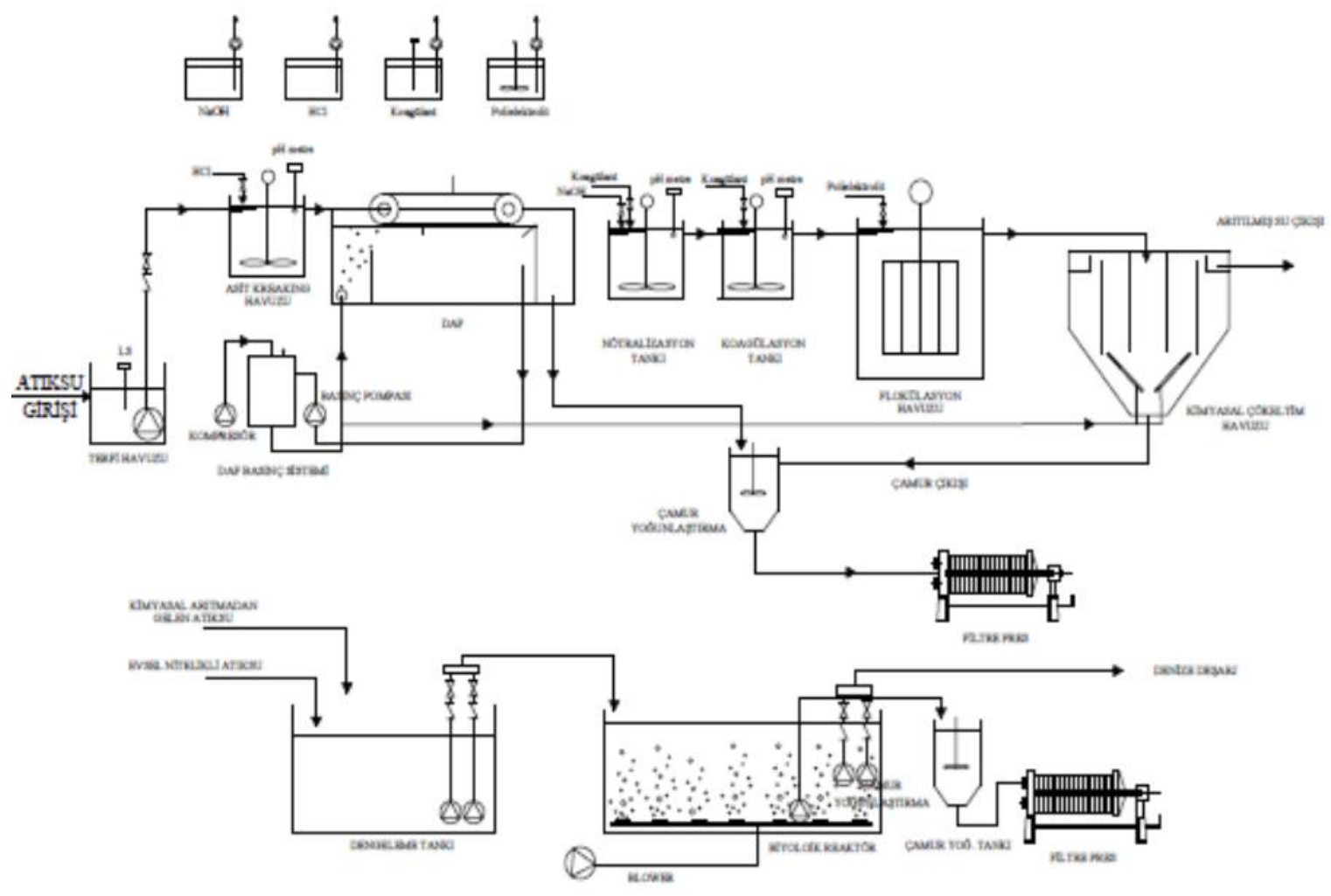

Şekil 3:

Atık Su Arıtma Tesisi Akım Şeması

Fiziksel, kimyasal ve biyolojik arıtma sisteminde oluşan çamurun bertarafına yönelik olarak iki ayrı çamur susuzlaştırma ünitesi uygulanması düşünülmüştür. Her iki ünitede de filtre pres kullanılacaktır. Yağ içeriği yüksek olan fiziksel ve kimyasal arıtma ünitesi için çamurun filtre bezine yapışmasını engelleyen yüzeyi teflon kaplı bezler ve basınç pompası olarak da 10 barlık basınç üreten ve çamurun flok yapısını bozmayan monopomp kullanilacaktır.

Biyolojik arıtma sisteminde oluşan çamur yapısı kimyasal ünitede oluşan çamur yapısından farklı olduğu için ayrı çamur susuzlaştırma ünitesi tasarlanmıştır. Bu ünitede çamur yoğunlaştırma için katyonik polielektrolit kullanılarak susuzlaştırma verimliliği arttırılacaktır.

\subsection{Arıtma Tesisi Üniteleri Verimleri}

Tasarlanan arıtma tesisinin, Asit Kraking + DAF, Kimyasal Arıtma, Biyolojik Arıtma proseslerinin her bir ünite bazında arıtım verimi hedefleri Tablo 5.'te verilmektedir. Buna göre, organik kirlilik \% 94 oranında azalacak ve tesis çıkışında verilen deşarj kriterlerinin altında olacaktır. Aynı şekilde AKM, yağ-gres, hidrokarbon (HC), fenol, toplam siyanür, sülfür ve pH'ın da deşarj kriterlerini sağlayacağı öngörülmektedir. 
Tablo 5. Atıksu Ünite Bazlı Arıtma Giderim Verimleri

\begin{tabular}{|c|c|c|c|c|c|c|c|c|c|c|c|}
\hline \multirow[t]{2}{*}{ Parametre } & \multirow[t]{2}{*}{$\begin{array}{c}\text { Atık- } \\
\text { su } \\
\text { Girişi } \\
\end{array}$} & \multicolumn{2}{|c|}{$\begin{array}{c}\text { Asit Kraking } \\
+ \\
\text { DAF }\end{array}$} & \multicolumn{3}{|c|}{ Kimyasal Aritma } & \multicolumn{4}{|c|}{ Biyolojik Arıtma } & \multirow{2}{*}{$\begin{array}{c}\text { Toplam } \\
\text { Aritma } \\
\text { Verimi } \\
\%\end{array}$} \\
\hline & & $\begin{array}{l}\text { Çıkış } \\
\text { Değ. }\end{array}$ & $\begin{array}{l}\text { Veri } \\
\mathrm{m} \%\end{array}$ & $\begin{array}{l}\text { Giriş } \\
\text { Değ. }\end{array}$ & $\begin{array}{l}\text { Çıkış } \\
\text { Değ. }\end{array}$ & $\underset{\%}{\text { Verim }}$ & $\begin{array}{l}\text { Giriş } \\
\text { Değ, }\end{array}$ & $\begin{array}{l}\text { Çıkış } \\
\text { Değ. }\end{array}$ & $\begin{array}{l}\text { SKKY } \\
\text { Tablo } \\
5.6-24 \\
\text { saatlik } \\
\end{array}$ & $\begin{array}{l}\text { Verim } \\
\%\end{array}$ & \\
\hline $\begin{array}{l}\mathrm{KOI} \\
(\mathrm{mg} / \mathrm{L})\end{array}$ & 450 & 297 & 34 & 297 & 112 & 62 & 112 & 24 & 400 & 78 & 94 \\
\hline $\begin{array}{l}\text { AKM } \\
(\mathrm{mg} / \mathrm{L})\end{array}$ & 150 & 82,2 & 45 & 82,2 & 8,25 & 90 & 8,25 & 6 & 60 & 27 & 96 \\
\hline $\begin{array}{l}\text { Yağ Gres } \\
(\mathrm{mg} / \mathrm{L})\end{array}$ & 500 & 50 & 90 & 50 & 16 & 68 & 16 & 9 & 40 & 43 & 98 \\
\hline $\begin{array}{l}\text { Hidro- } \\
\text { karbonlar } \\
\text { Pt-Co }\end{array}$ & 250 & 25 & 90 & 25 & 5 & 80 & 5 & 3,5 & 6 & 30 & 98 \\
\hline $\begin{array}{l}\text { Fenol } \\
(\mathrm{mg} / \mathrm{L})\end{array}$ & 0,1 & 0,1 & - & 0,1 & 0,08 & - & 0,08 & 0,06 & 2 & 25 & 40 \\
\hline $\begin{array}{l}\text { Toplam } \\
\text { Siyanür } \\
(\mathrm{mg} / \mathrm{L})\end{array}$ & 0,03 & 0,03 & - & 0,03 & 0,03 & - & 0,02 & 0,02 & 0,5 & 1 & 33 \\
\hline $\begin{array}{l}\text { Sülfür } \\
\text { (mg/L) }\end{array}$ & 0,1 & 0,1 & - & 0,1 & 0,09 & - & 0,09 & 0,05 & 2 & 44 & 50 \\
\hline $\mathrm{pH}$ & 8 & 2,5 & - & 2,5 & 8 & & 8 & 7,5 & $6-9$ & & \\
\hline
\end{tabular}

Arıtma tesisinin ilk ünitesi olan asit kraking + DAF ünitesinde KOİ, AKM, Yağ Gres, HC için sırasıyla \%34, \%45, \%90 ve \%90'lık bir giderim gerçekleşeceği hesaplanmıştır (Şekil 4).

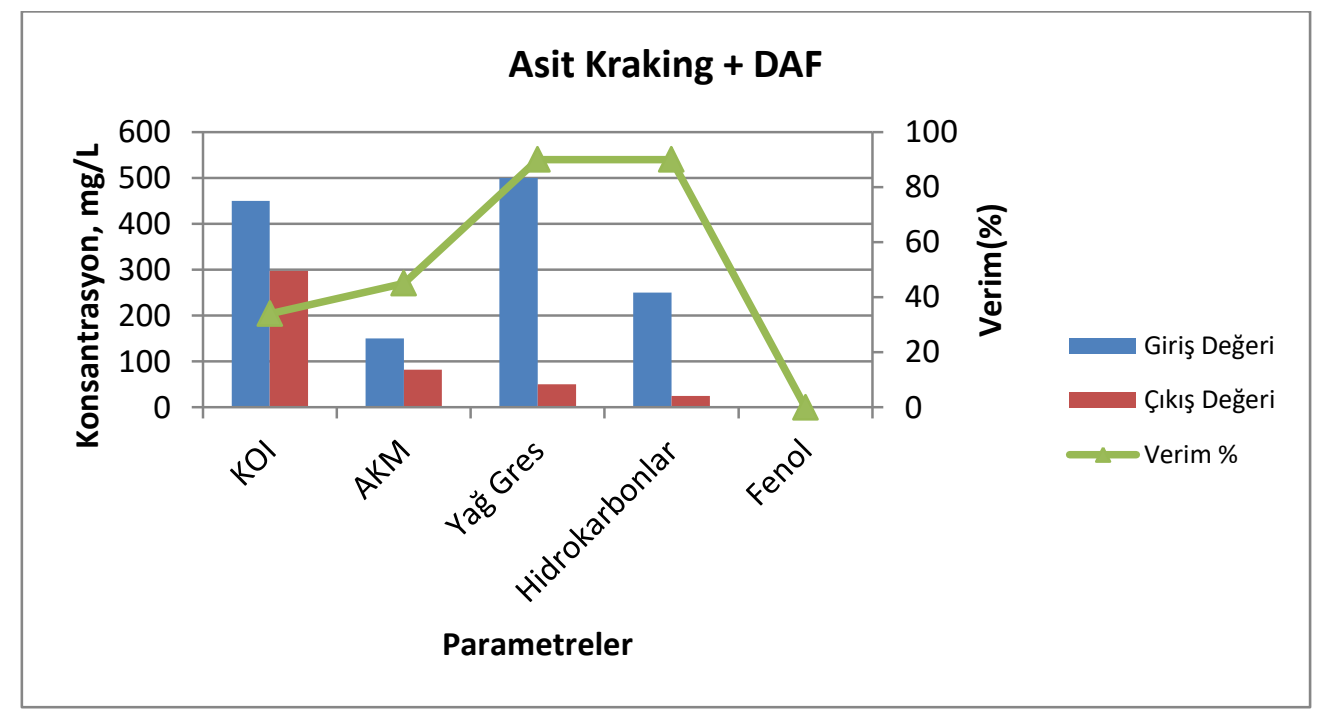

Sekil 4:

Asit Kraking-DAF Ünitesi Performanst

Kimyasal arıtım ünitesinde AKM ve hidrokarbonlar büyük oranda giderilmekte olup (\% 90 ve 80), KOİ ve yağ gres giderimi de kayda değerdir (\% 62 ve \%68) (Şekil 5.) 


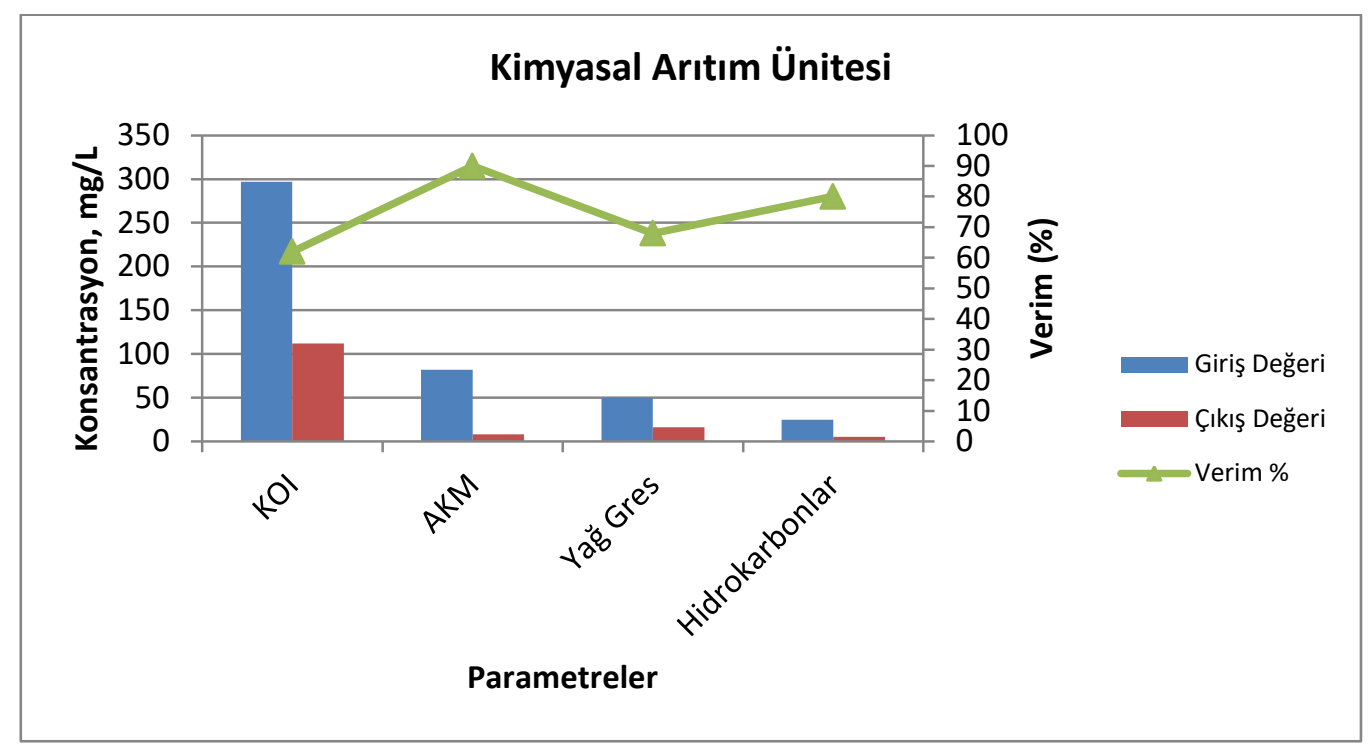

Şekil 5:

Arttma Tesisi Kimyasal Arttma Ünitesi Performansı

Petrol kirliliği, HC karışımının miktarı ve özelliğine göre kalıcılık gösterir. Petrol atığı ile kirlenmiş çevreden izole edilen pek çok mikroorganizma türü ile bu tür bileşikleri biyolojik olarak parçalamak mümkündür (Okerentugba ve Ezeronye, 2003). HC atıkları ile kirlenmiş sular, HC substratlarını karbon ve enerji kaynağı olarak tüketen, bu tür atıkları parçalama yeteneğine sahip mikroorganizma türlerinin gelişimini stimule eder. Petrol parçalama yeteneğine sahip pek çok bakteri türü mevcuttur (Darsa ve diğ, 2014). Bakterilerin atıktaki organik bileşikleri bozma yeteneğine bağlı olarak, petrol atık suları dahil olmak üzere organik yükü yüksek atıksuların arıtılması ile ilgili çok önemli çevresel sorunların üstesinden gelmede biyoteknolojik yöntemlerin çok etkili olduğu bilinmektedir (Al- Khalid ve Al-Nass, 2012, Darsa ve diğ, 2014, Ismaila ve. Khudhair, 2018). Fiziksel-kimyasal bir ön arıtımın biyolojik arıtmadan önce uygulanmasının toksisiteyi azaltacağı ve biyolojik arıtım performansını artıracağ1 literatürde belirtilmiştir (Beccari ve diğ.,1999) Bu çalışma kapsamında elde edilen bulgular da bu görüşü desteklemektedir.

Biyolojik arıtma ünitesi olarak uygulanacak olan AKR çıkışında elde edilmesi beklenen verimler KOİ için \%78, AKM için \%27, yağ-gres için \%43, HC için \% 30 ve fenol için $\% 25$ 'tir (Şekil 6). 


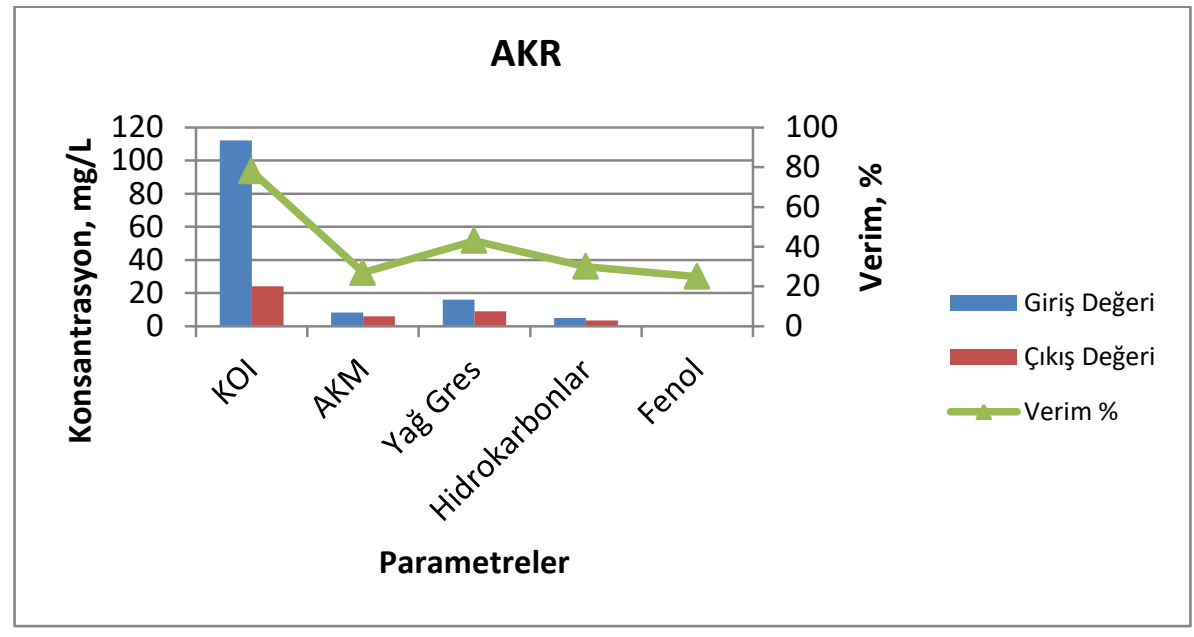

Şekil 6:

AKR Ünitesi Performanst

Tasarlanan arıtma tesisinin toplam verimi değerleri ele alındığında, çıkış suyu değerlerinin SKKY Deşarj Kriterlerini sağlayacağı görülmektedir ( Şekil 7.)

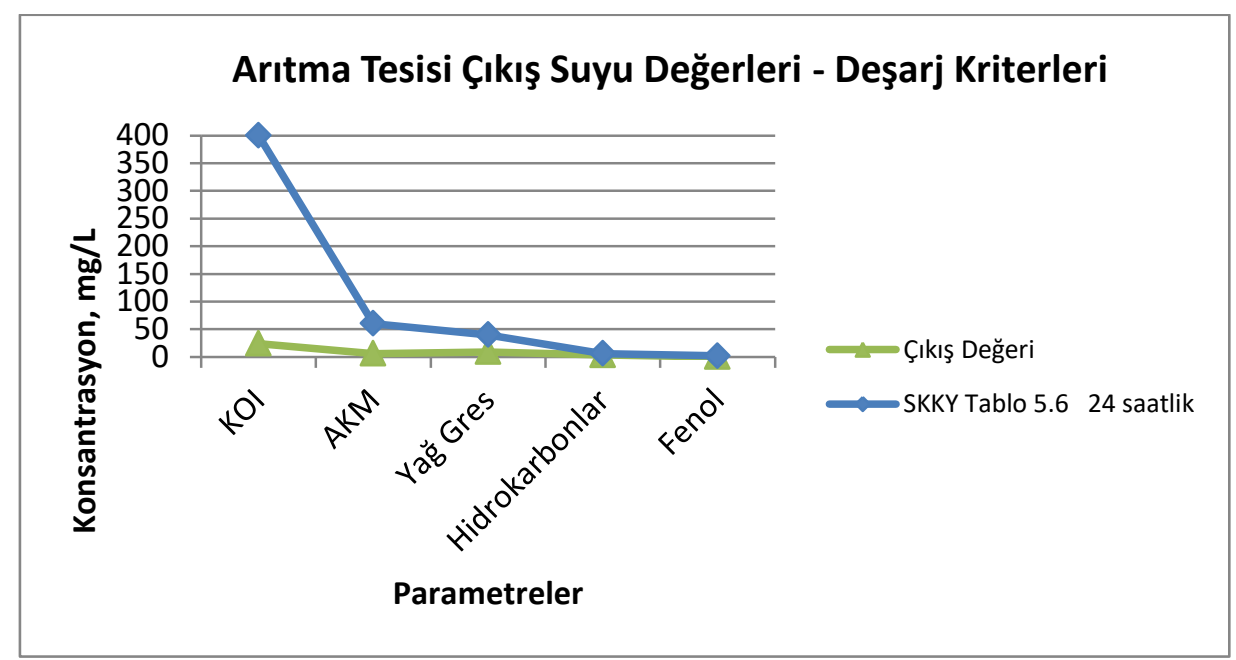

\section{Sekil 7:}

Arıtma Tesisi Çıkış Suyu Değerlerinin SKKY Deşarj Standarları ile Karşılaştırması

\section{SONUÇ}

Petrol içeren atık sularda sadece biyolojik prosesle arıtım yeterli olmamakta, buna karşın uygun bir fiziko-kimyasal ön arıtımın ardından biyolojik arıtımın uygulanması SKKY'de belirtilen deşarj kriterlerini sağlayacak düzeyde bir arıtım verimi sağlamaktadır.

$\mathrm{Bu}$ çalışmada gerçekleştirilen arıtılabilirlik çalışmaları sonucu yapılan atık su arıtma tesisi tasarımı ile KOİ , AKM, yağ-gres, hidrokarbon parametreleri için sırası ile \%94, \% 96, \%98 ve $\% 98$ oranında giderim verimi elde edilebilecektir. Yapılan bu çalışma ile arıtılacak akaryakıt depolama tesisi atık suyu, 31.12.2004 tarihinde 25687 sayılı Resmi Gazetede yayımlanan SKKY Tablo 11.2 Petrol Sanayii (Petrol Dolum Tesisleri ve Benzerleri)'nde belirtilen kriterleri sağlayarak deşarj edilecektir. 
Petrol içeren atık suların arıtılması konusu dünya çapında önem arz etmekte olup, bundan sonraki çalışmalarda kimyasal ihtiyacı az olan yenilikçi kimyasal arıtım teknolojileri ve yüksek organik yükte yüksek verim sağlayabilen biyolojik arıtım uygulamalarının geliştirilmesi üzerinde çalışılması uygun olacaktır.

\section{KAYNAKLAR}

1. AL-Khalid T., EL-Nass M. (2012) Aerobic biodegradation of phenols: acomprehensive review, Crit. Rev. Environ. Sci. Technol., 42, 1631-1690 doi: $10.1080 / 10643389.2011 .569872$

2. Ahmed, A.F., Ahmad, J., Basma, Y., Ramzi, T. (2007) Assessment ofalternative management techniques of tank bottom petroleum sludge in Oman; J. Hazard. Mater., 141, 557-564. https://doi.org/10.1016/j.jhazmat.2006.07.023

3. Beccari, M., Majone, M., Ricardi, C., Savarece, F., Torrisi, L. (1999) Integrated treatment of olive mill effluents: effect of chemical and physical pretreatment on anaerobic treatability, Water Sci. Technol. 40 (1), 347-355. https://doi.org/10.1016/S02731223(99)00383-2

4. Chen, G.H., He, G.H. (2003) Separation of water and oil from water -in- oil emulsion by freeze/thaw method, Sep. Purif. Technol., 31 (1),83-89. https://doi.org/10.1016/S1383$\underline{\text { 5866(02)00156-9 }}$

5. Machin-Ramirez C, Okoh Al, Morales D, Mayolo-Deloisa K, Quintero R. (2008). Slurryphase biodegradation of weathered oily sludge waste, Chemosphere, 70 (4), 737-744 https://doi.org/10.1016/j.chemosphere.2007.06.017

6. Darsa KV, Thatheyus A. J, Ramya D (2014) Biodegradation of Petroleum Compound Using the Bacterium Bacillus subtilis, Science International, 2 (1), 20-2 doi: 10.17311/sciintl.2014.20.255.

7. Khoufi, S., Aloui, F., Sayadi, S. (2006) Treatment of olive oil mill wastewater by combined process electro-Fenton reaction and anaerobic digestion, Water Res., 40, 2007- 2016. doi:10.1016/j.watres.2006.03.023

8. Okerentugba, P.O. and Ezeronye O.U. (2003) Petroleum degrading potentials of single and mixed microbial cultures isolated from rivers and refinery effluent in Nigeria. Arf. $J$. Biotechnol., 2, 288-292. https://doi.org/10.5897/AJB2003.000-1058

9. Sanaa J, Adewale G, Shadi W. H. (2015) Recent improvements in oily wastewater treatment: Progress, challenges, and future opportunities, Journal of Environmental Sciences, 37 (1) 5-30, https://doi.org/10.1016/j.jes.2015.04.011

10. Zainab Z. Ismaila, Haneen A.K. (2018) Biotreatment of real petroleum wastewater using non-acclimated immobilized mixed cells in spouted bed bioreactor, Biochemical Engineering Journal ,131 17-23. https://doi.org/10.1016/j.bej.2017.12.005 